\title{
Research on Turfgrass Water Use in Arizona
}

\author{
Charles F. Mancino \\ Department of Plant Sciences, University of Arizona, Tucson, AZ 85721
}

The economic importance of turfgrasses and other landscape materials cannot be argued on the state or national level. Nationally, expenditures for turf and sod are worth more than $\$ 25$ billion (Cockerham and Gibeault, 1985). According to estimates, Arizona's golf industry generates more than \$225 million in total annual expenditures for wages, nonlabor expenditures, and cost of goods sold (Barkley and Simmons, 1989). Arizona sod, sod installation, sprigging, hydroseeding, and hydrosprigging are valued at $\$ 11.2$ million/year in Arizona (C.C. Willis, Western Sod, Casa Grande, Ariz., personal communication, 1990). Arizona landscape services generate $\$ 240$ million in annual sales (Center for Business and Economic Research, 1986).

Despite the economic importance of turf, there is a need to conserve potable water used for irrigation. This is particularly true in Arizona, where groundwater is used for municipal, industrial, and agricultural purposes. Estimates show that lawn sprinkling represents $50 \%$ of total individual use (American Sod Producers Assn., 1989). The predicted water use of large (>4.05 ha) turfgrass facilities in the Phoenix and Tucson metropolitan areas is $7.09 \times 10^{7} \mathrm{~m}^{3} \cdot$ year $^{-1}$ and represents $1.6 \%$ of the total water demand (Arizona Dept. of Water Resources, 1984, 1988). Proposed limits on turfgrass water use will be $2.3 \times 10^{3}$ $\mathrm{m} \cdot \mathrm{ha}^{-1} \cdot$ year $^{-1}$ for Tucson and $2.4 \times 10^{3} \mathrm{~m} \cdot \mathrm{ha}^{-1} \cdot \mathrm{year}^{-1}$ for Phoenix. Scientific data have not been established to show if high-quality turf requires more water than this allotment. This may be particularly true where low-quality groundwater or wastewater is used for irrigation.

Turfgrass research in Arizona has three primary goals: 1) to develop a better understanding of turfgrass water requirements in the arid southwestern United States and provide weather-based soil moisture replacement values for turf; 2) to develop alternative grasses that require less water and maintenance and that can be used to replace currently available turfgrasses; and 3) to determine the long-term influence of low-quality irrigation water and wastewater effluent on turf and soil quality.

Research addressing the first goal includes year-round monitoring of bermudagrass [Cynodon dactylon (L.) Pers. and C. dactylon $x$ transvaalensisBurtt-Davy] and perennial ryegrass (Lolium perennet L.) turf water use. In one Arizona study, infrequently irrigated hybrid bermudagrasses with 0.9 -m-deep roots and grown in sandy loam (typic, udifluvent) soil used $854 \mathrm{~mm}$ water/year during 1989 and 1990 (Garrot et al., 1990, 1991). Rainfall accounted for $\approx 21 \%$ and $33 \%$ of turfgrass water use in 1989 and 1990, respectively. Annual water use averaged $62.4 \%$ of the reference evapotranspiration $\left(\mathrm{ET}_{0}\right)$ value derived from the modified Penman equation (Pruitt and Doorenbos, 1977) and provided by the Arizona Meteorological Network (Brown, 1989). This percentage was not static and ranged from $95 \% \mathrm{ET}_{0}$ at $100 \%$ soil water-holding capacity to $18 \% \mathrm{ET}_{0}$ at $34 \%$ water-holding capacity (Garrot et al., 1991). Of the water used by the turf, 50\%, 30\%, and 20\% was derived from the 0 - to 30-, 31- to 60-, and 61- to 90-cm soil depths, respectively. Turf quality was considered to be high.

Earlier work by Kneebone and Pepper (1982) in southern Arizona showed that bermudagrass turf overseeded in the winter with annual ryegrass (L. multiflorum Lam.) and grown under well-watered conditions required $1661 \mathrm{~mm}$ water. This number represented $58 \%$ of class A pan evaporation and would equal $\approx 83 \% \mathrm{ET}_{\mathrm{o}}$. Kopec et al. (1990) found that well-watered hybrid bermudagrass grown in Tucson from 16 June to 15 Oct. 1989 in 7.6-liter nursery pails $(20.3 \mathrm{~cm}$ top diameter $\times 20 \mathrm{~cm}$ depth) filled with 20 -grain $(1.3 \mathrm{~mm}$ in diameter) silica sand used $470 \mathrm{~mm}$ water. This water use represented $84 \% \mathrm{ET}_{0}$. Perennial ryegrass grown in the same containers used $428 \mathrm{~mm}$ water over 72 measurement days between 16 Oct. 1989 and 15 June 1990. Ryegrass water use ranged from $58 \% \mathrm{ET}_{0}$ during chilling temperatures $(-5$ to $+3 \mathrm{C}$ ) to $100 \%$ and $110 \% \mathrm{ET}_{0}$ during high temperatures (35 to $37 \mathrm{C}$ ) (Kopec et al., 1988, 1990). Kopec et al. (1991) determined that lysimeter-grown, well-watered bermudagrass turf overseeded with winter ryegrass required $1549.4 \mathrm{~mm}$ water/year. These well-watered turfs very likely exhibited some luxury water consumption-water use exceeding actual plant need. Kneebone and Pepper ( 1984) showed that ET losses from well-watered turf could significantly exceed pan evaporation.

Low-water-requiring grasses with functional and aesthetic values and low maintenance requirements are being developed throughout the western United States. Active research programs are underway in Arizona, California, Colorado, Nebraska, New Mexico, Oklahoma, and Texas. Arizona's program involves developing the native rangegrass Hilaria belangeri (Steud.) Nash as a turf through breeding and evaluation. This grass requires only rainfall for survival in southem Arizona. Fifteen $H$. belangeri clones, selected from >100 ecotypes collected in southern Arizona, were established in replicated field plots in Tucson and Safford to quantify genetic variation in turf traits. Broad-sense heritabilities for color were 0.63 and 0.78 in Tucson and Safford, respectively. Leaf length ranged from 26.5 to $102 \mathrm{~mm}$ and had a heritability of 0.43 in Tucson and 0.40 in Safford (Mancino and Ralowicz, 1990). Leaf width ranged from 8 to $13 \mathrm{~mm}$, and heritability estimates were 0.18 and 0.11 in Tucson and Safford, respectively. Heritability of density was 0.48 in Tucson and 0.71 in Safford. Narrow-sense heritability data need to be established. In addition, irrigated $H$. belangeri maintained as uncut swards or at mowing heights of 5 and $10 \mathrm{~cm}$ during 1989 and 1990 averaged 39\%, 42\%, and $44 \%$ groundcover, respectively, in Mar. 1990. These averages increased to $82 \%, 81 \%$, and $82 \%$ groundcover by Oct. 1990 (Mancino and Ralowicz, 1990). Poor color and quality was evident in uncut plots, an indication that irrigated $H$. belangeri swards should be mowed. Buffalograsses [Buchloe dactyloides (Nutt.) Englem], lovegrass (Eragrostis lehmanniana Nees), gramagrasses (Bouteloua sp.), and yellow bluestem [Bothriochlora ischaemum (L.) Keng] are also forming perennial swards under routine mowing and irrigation in southern Arizona (D.M. Kopec, personal communication, 1991).

Little information is available at this time on the impact of secondary wastewater effluent irrigation on turfgrass and soil quality. Wastewater potentially could replace potable water as irrigation water for turf. New turfgrass facilities constructed in the Tucson metropolitan area will be required to use effluent water for their irrigation needs. Wilson et al. (1988) estimated landscape materials will use $5.7 \times 10^{7} \mathrm{~m}^{3}$ effluent water/year by 2030 in Tucson alone. Although effluent water can provide nutrients for turfgrass growth, it also can result in salt deposition, particularly sodium, in the soil. Pepper et al. (1978) found that applying secondarily treated wastewater to a soil-turf filter in excess of the turf's water requirements would reclamate the wastewater as it passed through the turfgrass root system. The soil-turf system removed excess $\mathrm{N}, \mathrm{B}, \mathrm{P}, \mathrm{Ca}, \mathrm{Mg}$, virus particles, and coliform bacteria. Recent research evaluated how effluent irrigation of turf altered turfgrass and soil quality. Hayes et al. (1990a) found that, although high-quality effluent water had little detrimental effect on soil quality, it did increase soil salinity and Na content. Soil irrigated with effluent always maintained adequate $\mathrm{P}, \mathrm{K}$, and $\mathrm{S}$ levels for turfgrass growth. Iron, $\mathrm{Mn}, \mathrm{Cu}$, and $\mathrm{Zn}$ did not accumulate in this turf soil.

Hayes et al. (1990b) showed that little additional fertilizer $\mathrm{N}$ and no $\mathrm{P}$ or $\mathrm{K}$ were required for turf growth when irrigated with effluent. Iron chlorosis was more prevalent in effluent-irrigated turf plots, perhaps due to its precipitation from soil solution by $\mathrm{P}$ delivered in the effluent. Effluent-irrigated perennial ryegrass turf receiving any additional $\mathrm{N}$ fertilizer had high levels of heat stress and a rapid decline in turf quality during high temperatures. Results from these studies indicate that $\mathrm{N}$ fertilizer applications on overseeded perennial ryegrass should be avoided beginning in March. Rye and bermudagrass seeding rates should be increased by $\approx 5 \%$ to account for seedling death due to salinity. Phosphorous and $\mathrm{K}$ fertilizer rates can be reduced, but Fe rates should be increased to prevent chlorosis. 
Research in Arizona continues in each of the three areas mentioned above. Datacollected to date on turfgrass water requirements indicates that $65 \%$ to $80 \%$ ET $_{0}$ will provide acceptable or better than acceptable quality bermudagrass. High-quality perennial ryegrass may require 95\% $\mathrm{ET}_{0}$ during high-temperature stress (Kopec et al., 1990). However, if facilities are to meet mandatory irrigation water limits set by the Arizona Dept. of Water Resources $(1984,1988)$, they must maintain an annual average $\mathrm{ET}_{0}$ of $\approx 65 \%$. This level might be achieved through irrigating deeply and infrequently and avoiding luxury water consumption by the turf. Substituting low-water-requiring grasses in low-maintenance turfgrass areas may also reduce water demand. Hilaria belangeri may provide an acceptable groundcover due to its ability to form a loose sod of sufficiently fine leaf texture and acceptable green pigmentation. Irrigation with wastewater, while not reducing turf water requirements, can reduce a turfgrass facilities' dependence on potable groundwater for irrigation. In addition, wastewater irrigation may allow facilities to reduce the N, P, K, and S levels applied to turf.

\section{Literature Cited}

American Sod Producers Association. 1989. Outdoor watering bans: Symbolism or good sense? Turfgrass Environ. 1:19.

Arizona Dept. of Water Resources. 1984. Phoenix active management area. Management plan for first management period: 1980-1990. Arizona Dept of Water Res., Phoenix.

Arizona Dept. of Water Resources. 1988. Tucson active management area Draft management plan for second management period: 1990-2000. Arizona Dept. of Water Res., Phoenix.

Barkley, D.L. and L. Simmons. 1989. Contribution of the golf industry to the Arizona economy. Univ. of Arizona Tech. Bul. 263.

Brown, P.W. 1989. Accessing the Arizona Meteorological Network by computer. Univ. of Arizona Coop. Ext. Bul. 8733.

Center for Business and Economic Research. 1986. The economic impact of Arizona's green industry. Arizona State Univ., Tempe.

Cockerham, S.T. and V.A. Gibeault. 1985. The size, scope, and importance of the turfgrass industry, p. 7-12. In: V.A. Gibeault and ST. Cockerham (eds.). Turfgrass water conservation. Univ. of California Coop. Ext. Publ. 21405.

Carrot, D.J., C.F. Mancino, D.D. Fangmeier, and A. Maricic. 1990. Minimum water requirements of three hybrid bermudagrasses under southern Arizona conditions. Agron. Abstr. p. 178.

Carrot, D.J., C.F. Mancino, and A. Maricic. 1991. Consumptive water use of three high quality bermudagrasses under a deep and infrequent irrigation regime. In: D.M. Kopec (ed.). 1991 Turfgrass and ornamentals research summary. Univ. of Arizona Coop. Ext. Bul. Ser. P-86.

Hayes, A.R., C.F. Mancino, and I.L. Pepper. 1990a. Irrigation of turfgrass with secondary sewage effluent-I: Soil and leachate quality. Agron. J. 82:939943.

Hayes, A.R., C.F. Mancino, W.Y. Forden, D.M. Kopec, and I.L. Pepper. 1990b. Irrigation of turfgrass with secondary sewage effluent-II. Turf quality. Agron. J. 82:943-946.

Kneebone, W.R. and I.L. Pepper. 1982. Consumptive water use by subirrigated turfgrasses under desert conditions. Agron. J. 74:419-423.

Kneebone, W.R. and I.L. Pepper. 1984. Luxury water use by bermudagrass. Agron. J. 76:999-1002.

Kopec, D.M., P.W. Brown, C.F. Mancino, and J.J. Gilbert. 1991. Water use and crop coefficients for warm and cool season turfgrasses in the desert. Agron. Abstr. p. 178.

Kopec, D.M., P.W. Brown, C.F. Mancino, and D.C. Slack. 1990. Developing crop coefficients for desert turfgrass-Calibrating reference ET with turf water use. Amer. Soc. Agr. Eng. Publ. 04-90:181-185.

Kopec, D.M., P.W. Brown, C.F. Mancino, D.C. Slack, and L.F. Salo. 1988. Desert turfgrass crop coefficients. Agron. Abstr. p. 153.

Mancino, C.F. and A.E. Ralowicz. 1990. Breeding and development of curly mesquitegrass. U.S. Golf Assn. Green Section Annu. Turfgrass Res. Rpt.

Pepper, I.L., W.R. Kneebone, and P.R. Ludovici. 1978. Water reclamation by the use of soil-turfgrass systems in the southwest USA. Office of Water Research and Technology (B-072-ARIZ), U.S. Dept. of Interior, Washington, D.C.

Pruitt, W.O. and J. Doorenbos. 1977. Empirical calibration a requisite for evapotranspiration formulae based on daily or longer mean climatic data. Proc. Intl. Round Table Conf. Evapotranspiration, Budapest, Hungary.

Wilson, P.N., T.J. Goldhammer, and J.C. Wade. 1988. Bioeconomic considerations for wastewater reuse in agricultural production. Water Res. Bul. $24: 1-9$ 